Short report

\title{
Neuropeptides in gliomas: identification of somatostatin 14 in a medulloblastoma
}

\author{
DE BATEMAN, JR MCDERMOTT, RH PERRY, RDIMALINE,* JA BIGGINS, \\ JA EDWARDSON \\ From the MRC Neuroendocrinology Unit, Newcastle General Hospital, Newcastle upon Tyne and MRC \\ Secretory Control Group, * Physiological Laboratory, University of Liverpool, Liverpool, UK
}

SUMMARY Forty nine gliomas were analysed for the following neuropeptides: somatostatin (SS), substance $\mathrm{P}$ (SP), neurotensin (NT) and vasoactive intestinal polypeptide (VIP) and the pituitary peptide, adrenocorticotrophin (ACTH). A significant amount of authentic SS was found in a medulloblastoma, and low concentrations of SP and NT immunoreactivity in an ependymoma and cerebellar astrocytoma respectively. The majority of the other gliomas did not contain detectable levels of these five neuropeptides. Low levels of neuropeptides were found in some specimens probably due to contamination with cerebral cortex.

A number of different neuropeptides are found in non-CNS tumours, ${ }^{1}$ but, despite the common embryological origin of neurons and glia, there has been no systematic study of neuropeptides in gliomas. A number of previous observations suggest that gliomas may contain neuropeptides. Hara et al ${ }^{2}$ found positive immunostaining for somatostatin (SS), insulin and glucagon in gliomas, and substance $\mathbf{P}(\mathrm{SP})^{3}$ and vasoactive intestinal polypeptide (VIP) ${ }^{4}$ immunoreactivity have been found in the $\mathrm{C} 6$ glioma. We have therefore analysed 49 glioma biopsy specimens for the following neuropeptides: somatostatin, substance $P$, neurotensin (NT), vasoactive intestinal polypeptide, and the pituitary peptide, adrenocorticotrophin (ACTH).

\section{Materials and methods}

Biopsy specimens of gliomas were collected on ice at the time of removal from the patient. Three samples of normal cortex were also obtained from tissue removed for access at neurosurgery. Any visible cortex and white matter were dissected

Address for reprint requests: Dr DE Bateman, Wessex Neurological Centre, Southampton General Hospital, Shirley, Southampton SO9 4XY, UK.

Received 7 May 1985 and in revised form 20 November 1985. Accepted 23 November 1985 off and the tumour was then immediately homogenised in ice-cold $0.1 \mathrm{~N} \mathrm{HCl}(10 \mathrm{vol})$ using a teflon pestle. The homogenate was centrifuged $(1200 \mathrm{~g} ; 15 \mathrm{~min})$ and the supernatant stored at $-70^{\circ} \mathrm{C}$ until assay. An adjacent portion of the biopsy specimen was fixed in formalin and paraffin processed to determine the histological diagnosis and assess the degree of contamination of the tumour sample with cerebral cortex using standard histological stains.

At the time of assay the supernatant was thawed and neutralised using $5 \mathrm{~N}-\mathrm{NaOH}$. The neutralised sample was centrifuged using a Burkard microcentrifuge, and the concentrations of some or all of the various peptides determined by RIA using previously published procedures: $\mathrm{SS} ;{ }^{5} \mathrm{SP} ;{ }^{6} \mathrm{NT} ;{ }^{7}$ and ACTH. ${ }^{8}$ The SS antiserum recognised both SS-14 and the SS-28 synthetic peptide. The SP antiserum was directed against the C-terminus of the peptide and the NT antiserum was directed against a sequence near the $\mathrm{N}$-terminus. The ACTH antiserum cross-reacted with corticotrophin-like intermediate lobe peptide (CLIP); $\mathrm{ACTH}_{18-39} .^{9}$ The VIP antiserum was specific for the C-terminal region of VIP. ${ }^{10}$ All positive samples were further assayed if possible at $1 / 2$, $1 / 4$ and $1 / 8$ dilutions to establish parallelism of the immunoreactive material.

\section{Results and discussion}

The concentrations of some or all of the five neuropeptides were determined in $\mathbf{4 9}$ gliomas comprising 24 astrocytomas, 11 oligodendrogliomas, five glioblastomas, four cystic astrocytomas of the cere- 
bellum, four ependymomas and one medulloblastoma (table). The concentration of the peptides in normal cortex are shown for comparison. No detectable ACTH or CLIP-like immunoreactivity was found in any of the 21 tumour extracts assayed. Most tumours were assayed for more than one neuropeptide and in the majority of these analyses $(57 / 102)$, levels of the four other peptides (SS, SP, NT and VIP) were below detectable limits. Of those 45 analyses which had detectable levels of neuropeptides, the levels found were, with two exceptions (DW and MS), considerably lower than the levels found in normal human biopsy cortex. Cortex was demonstrable histologically in 37 of these 45 positive analyses in contrast to samples which were negative for neuropeptides where cortex was absent in 43 out of 57 cases. Since all these four neuropeptides (SS, SP, NT and VIP) are found in normal human biopsy cortex, these results strongly suggest that the low levels of immunoreactivity found in the glioma biopsy specimens are due to contamination with cortex. In addition most specimens were either completely negative for all the neuropeptides assayed or contained more than one cortical neuropeptide (14/23) supporting

Table Levels of neuropeptides in tumour extracts

\begin{tabular}{|c|c|c|c|c|c|c|c|}
\hline Patient & Tumour type & $A C T H$ & $\begin{array}{l}\text { SS } \\
\mathrm{pmol} / \mathrm{g}\end{array}$ & $\begin{array}{l}S P \\
\mathrm{pmol} / \mathrm{g}\end{array}$ & $\begin{array}{l}\mathrm{NT} \\
\mathrm{pmol} / \mathrm{g}\end{array}$ & $\begin{array}{l}\text { VIP } \\
\mathrm{pmol} / \mathrm{g}\end{array}$ & Cortex $\dagger$ \\
\hline \multicolumn{8}{|l|}{ Normal } \\
\hline E.L. & Astrocytoma & $\begin{array}{l}<0.1 \\
<0.1\end{array}$ & $<0.3$ & $\begin{array}{l}<0.4^{1} \\
11.9\end{array}$ & $<0 . \frac{1}{3}$ & 0112 & - \\
\hline $\begin{array}{l}\text { G.J. } \\
\text { A.L. }\end{array}$ & $"$ & $<0.1$ & $<0.3$ & $<0.4$ & & & $\stackrel{+}{-}$ \\
\hline F.R. & $"$ & & $<0.3$ & $<0.4$ & & & - \\
\hline A.R. & $"$ & & $12 \cdot 2$ & 0.6 & 3.0 & & + \\
\hline P.M. & $"$ & & & $<0.4$ & & & - \\
\hline $\begin{array}{l}\text { D.W. } \\
\text { I.B. }\end{array}$ & $"$ & & $72 \cdot 6$ & 17.8 & & & + \\
\hline $\begin{array}{l}\text { I.B. } \\
\text { G.L. }\end{array}$ & $"$ & $<0.1$ & $5 \cdot 1$ & $<0.4$ & 0.6 & & + \\
\hline $\begin{array}{l}\text { G.L. } \\
\text { D.M. }\end{array}$ & ” & & $<0.3$ & $1 \cdot 3$ & $<0.3$ & & $\stackrel{+}{-}$ \\
\hline D.B. & $"$ & $<0.1$ & $<0.3$ & & & & - \\
\hline S.L. & $"$ & $<0.1$ & 5.5 & & $<0.3$ & 0.63 & + \\
\hline H.G. & $"$ & $<0.1$ & $1 \cdot 2$ & & & $<0.15$ & - \\
\hline $\begin{array}{l}\text { I.F. } \\
\text { A.H. }\end{array}$ & $"$ & $\begin{array}{l}<0.1 \\
<0.1\end{array}$ & & & & & $\overline{-}$ \\
\hline E.H. & $"$ & & $3 \cdot 1$ & & $<0.3$ & & + \\
\hline K.J. & $"$ & & $89 \cdot 1$ & & 0.9 & 1.23 & + \\
\hline E.R. & $"$ & & $8 \cdot 5$ & & & 0.5 & + \\
\hline G.F. & $"$ & & $3 \cdot 1$ & & $<0.3$ & $<0.15$ & + \\
\hline G.P. & $"$ & & 10.9 & & $<0.3$ & $<0.15$ & - \\
\hline $\begin{array}{l}\text { El.H. } \\
\text { F w }\end{array}$ & $"$ & & $18 \cdot 3$ & & & 0.5 & + \\
\hline E.W. & $"$ & & $15 \cdot 2$ & & $<0.3$ & 0.5 & + \\
\hline $\begin{array}{l}\text { J.R. } \\
\text { J.T. }\end{array}$ & $"$ & & $10 \cdot 3$ & & & $\begin{array}{r}0.48 \\
<0.15\end{array}$ & + \\
\hline M. & Oligodendroglioma & $<0.1$ & $1 \cdot 2$ & $<0.4$ & 1.5 & & $\begin{array}{l}+ \\
+\end{array}$ \\
\hline K.C. & , & $<0.1$ & $<0.3$ & $<0.4$ & $<0.3$ & $<0.15$ & - \\
\hline I.T. & $"$ & $<0.1$ & $<0.3$ & $<0.4$ & $<0.3$ & & + \\
\hline R.P. & $"$ & $<0.1$ & $2 \cdot 6$ & $5 \cdot 4$ & $2 \cdot 7$ & $<0.15$ & + \\
\hline $\begin{array}{l}\text { R.S. } \\
\text { D.S. }\end{array}$ & $"$ & $\begin{array}{l}<0.1 \\
<0.1\end{array}$ & $\begin{array}{r}68.4 \\
<0.3\end{array}$ & & 0.78 & $<0.15$ & $\stackrel{+}{-}$ \\
\hline M.S. & $”$ & & $<0.3$ & $14 \cdot 1$ & & & $\overline{+}$ \\
\hline D.B. & $"$ & $<0.1$ & $6 \cdot 3$ & & & & + \\
\hline K.S. & $"$ & & $23 \cdot 2$ & & & $<0.15$ & - \\
\hline B.U. & $"$ & & 336 & & 0.97 & & + \\
\hline $\begin{array}{l}\text { M.D. } \\
\text { P.S. }\end{array}$ & Astro"vtoma cerehellum & & 43.9 & & & 0.84 & + \\
\hline $\begin{array}{l}\text { P.S. } \\
\text { S.J. }\end{array}$ & Astrocytoma cerebellum & $<0 \cdot 1$ & $<0.3$ & $<0.4$ & $<0.3$ & $<0.15$ & - \\
\hline $\begin{array}{l}\text { S.J. } \\
\text { R.P. }\end{array}$ & $"$ & $<0.1$ & $\begin{array}{l}<0.3 \\
<0.3\end{array}$ & $<0.4$ & $<0.3$ & $\begin{array}{l}<0.15 \\
<0.15\end{array}$ & $\bar{z}$ \\
\hline M.R. & Glinh" & & & & $2 \cdot 3$ & & + \\
\hline $\begin{array}{l}\text { K.C. } \\
\text { P.E. }\end{array}$ & Glioblastoma multiforme & $\begin{array}{l}<0.1 \\
<0.1\end{array}$ & $\begin{array}{l}<0.3 \\
<0.3\end{array}$ & $<0.4$ & & & $\bar{z}$ \\
\hline I.H. & ” & & & & 0.85 & $<0.15$ & - \\
\hline J.R. & $"$ & & $<0.3$ & & & & - \\
\hline $\begin{array}{l}\text { Ed.H. } \\
\text { I.M. }\end{array}$ & Medulloblastoma & & 28 & & & & + \\
\hline $\begin{array}{l}\text { I.M. } \\
\text { A.B. }\end{array}$ & $\begin{array}{l}\text { Medulloblastoma } \\
\text { Ependymoma }\end{array}$ & & $22 \cdot 6$ & & & & - \\
\hline $\begin{array}{l}\text { A.B. } \\
\text { J.M. }\end{array}$ & " & & $<0.3$ & & $<0.3$ & & $\overline{-}$ \\
\hline P.S. & $"$ & & & $<0.4$ & & & - \\
\hline H.S. & $" \quad$ (cord) & $<0.1$ & $<0.3$ & 0.4 & $<0.3$ & & - \\
\hline
\end{tabular}

*The values for fresh biopsy normal cortex are shown for comparison. †Presence or absence of cortex found on histological examination. 
this conclusion.

In two specimens (MS and DW) the level of SP was greater than that in normal cortex. Contamination with cortex was present in the sample from MS, so despite the failure to detect SS it is not possible to be certain that the tumour itself was the source of the high SP concentration. In the specimen DW, the level of SP was considerably elevated in relation to that of SS and together with the finding that SP was twice the normal level in adjacent infiltrated cortex in one specimen, suggests that in some cases infiltration of the cortex by a glioma may affect the processing of SP.

Three specimens contained amounts of neuropeptide not attributable to contamination with normal tissue. The single medulloblastoma examined contained a significant amount of SS $(22.6 \mathrm{pmol} / \mathrm{g})$ and was entirely composed of tumour. HPLC analysis of this material showed that it consisted of two peaks (fig), the major peak corresponding to SS-14 and a smaller unidentified later-eluting peak. A spinal cord ependymoma, entirely composed of tumour, contained SP $(0.4 \mathrm{pmol} / \mathrm{g})$ and a cystic astrocytoma of the cerebellum, contained neurotensin $(2 \cdot 3 \mathrm{pmol} / \mathrm{g})$.

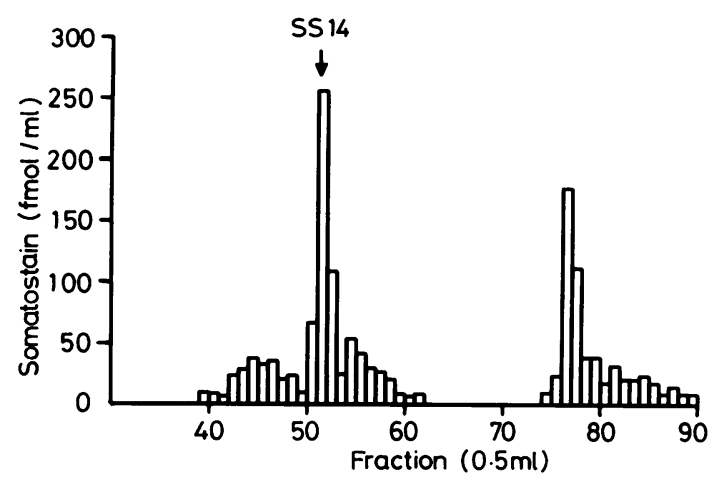

Fig HPLC profile of somatostatin immunoreactivity in an extract of medulloblastoma. The tumour was extracted with $0 \cdot 1 \mathrm{~N} \mathrm{HCl}$ and the extract chromatographed on a Nova-Pak $C 18$ radial compression cartridge, eluting at $1 \mathrm{ml} / \mathrm{min}$ with a linear gradient ( $30 \mathrm{~min}$ ) from $21 \%$ to $38.5 \%$ acetonitrile containing $11 \mathrm{mM}$-trifluoroacetic acid. $0.5 \mathrm{ml}$ fractions were collected, dried and somatostatin immunoreactivity determined by $R I A$.

These results suggest that the majority of gliomas do not contain these neuropeptides. This is in contrast to a recent immunohistochemical study, ${ }^{2}$ in which it was reported that SS immunostaining was found in most tumour cells in astrocytomas. The degree of immunostaining shown in the photographs suggest that SS, if genuinely present in astrocytomas, should be present in greater amounts than in normal cortex, which we have found not to be the case (table). The
HPLC profile of SS immunoreactive material in the medulloblastoma showed an additional peak of immunoreactivity not due to somatostatin which emphasises the point that positive immunostaining may be non-specific, though differences in antibody specificity might also account for these differing results. Further carefully controlled immunocytochemical studies of neuropeptides in gliomas are required to settle the matter.

The finding of somatostatin in a medulloblastoma supports recent suggestions that these tumours may arise from a stem cell capable of both neuronal and glial differentiation, ${ }^{11}$ and the absence of neuropeptides in the majority of gliomas possibly reflects their origin from a more differentiated cell capable only of glial differentiation. Further studies of medulloblastomas for neuropeptides would obviously be of interest.

The authors thank the neurosurgeons of the Regional Neurological Centre, Newcastle, for the provision of specimens. The study was in part supported by the North East Branch of the Cancer Research Campaign.

\section{References}

${ }^{1}$ Rees LH. Ectopic Humoral Syndromes: Recent Advances in Medicine. Churchill Livingstone, 1981;18:261-83.

${ }^{2}$ Hara H, Toshiaki, Moriki, Miyao M, Hashimoto $\mathbf{M}$, Yamane $T$. Localisation of somatostatin in human brain tumours. No To Shinkei 1983;35:553-8.

${ }^{3}$ Harkins J, Roper M, Ham RG, Stewart JM. Biosynthesis of substance $P$ in cultured mouse neuroblastoma and rat glioma cells. Brain Res 1978;147:405-9.

${ }^{4}$ Said SI, Rosenberg RN. Vasoactive intestinal polypeptide: abundant immunoreactivity in neural cell lines and normal nervous tissue. Science 1976;192:907-8.

${ }^{5}$ Penman E, Wass JAH, Lund A, et al. Development and modulation of a specific radioimmunoassay for somatostatin in human plasma. Ann Clin Biochem 1979;16:15-25.

${ }^{6}$ McGregor GP, Bloom SR, Lowry RG, eds. Substance P in radioimmunoassay of gut regulatory peptides. 1982:154-63.

${ }^{7}$ Carraway R, Leeman SE. Radioimmunoassay for neurotensin, a hypothalamic peptide. J Biol Chem 1976;250: $1907-11$.

${ }^{8}$ Rees LH, Cook DM, Kendall JW, et al. A radioimmunoassay for rat plasma ACTH. Endocrinology 1979;104:1845-952.

${ }^{9}$ Smith AI, Keith AB, Edwardson JA, Biggins JA, McDermott JR. Characterisation of corticotrophin-like immunoreactive peptides in rat brain using high performance liquid chromatography. Neurosci Lett 1982;30:130-8.

${ }^{10}$ Dimaline R, Dockray GJ. Multiple immunoreactive forms of vasoactive intestinal polypeptide in human colonic mucosa. Gastroenterology 1978;75:387-92.

${ }^{11}$ Rorke LB. The cerebellar medulloblastoma and its relationship to primitive neuroectodermal tumours. $J$ Neuropathol Exp Neurol 1983;42:1-15. 